Archive for

Organic Chemistry

Arkivoc 2018, part ii, 40-49

\title{
Preparation, structure, and oxidative reactivity of (dichloroiodo)pyridines: recyclable hypervalent iodine reagents
}

\author{
Akira Yoshimura, ${ }^{* a, b}$ Khiem C. Nguyen, ${ }^{b}$ Victor N. Nemykin, ${ }^{c}$ and Viktor V. Zhdankin*a,b \\ ${ }^{a}$ The Tomsk Polytechnic University, 634050 Tomsk, Russia \\ ${ }^{b}$ Department of Chemistry and Biochemistry, University of Minnesota Duluth, \\ Duluth, Minnesota, 55812, USA \\ ${ }^{c}$ Department of Chemistry, University of Manitoba, Winnipeg, MB R3T 2N2, Canada \\ Emails: ayoshimu@d.umn.edu vzhdanki@d.umn.edu
}

Dedicated to Prof. Kenneth K. Laali on the occasion of his 65th birthday

Received 07-26-2017

Accepted 09-22-2017

Published on line $10-11-2017$

\section{Abstract}

New pyridine-based hypervalent iodine reagents, (dichloroiodo)pyridines, were prepared by chlorination of 2-, 3-, or 4-iodopyridines with $\mathrm{NaOCl}-\mathrm{HCl}$ at room temperature. Structures of 2-(dichloroiodo)pyridine and 2(dichloroiodo)-3-propoxypyridine were established by X-ray crystallography. The new (dichloroiodo)pyridines can be used as efficient reagents for oxidation of alcohols to carbonyl compounds and also as chlorinating reagents. The reduced form of the reagents such as 2-iodo-3-propoxypyridine, can be recovered from the reaction mixture in good yields by an acid-base liquid-liquid biphasic protocol.

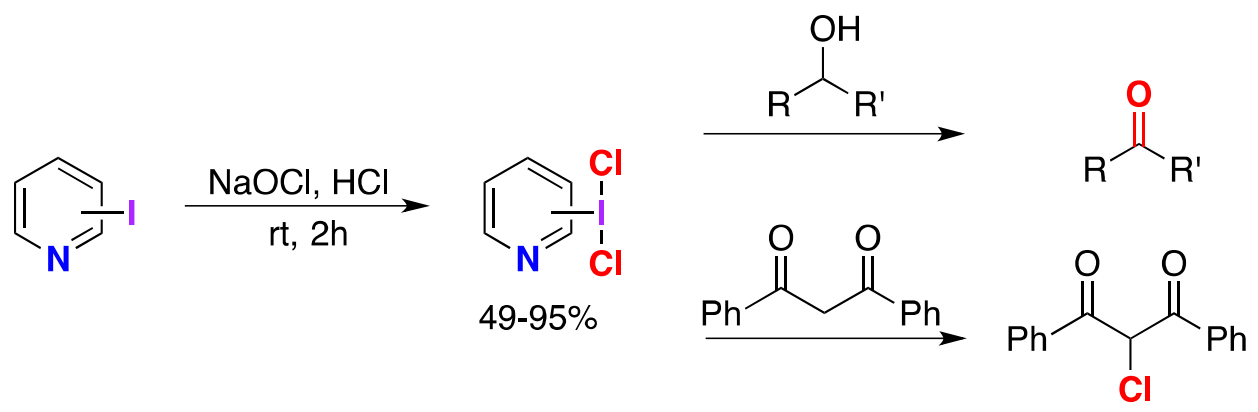

Keywords: Hypervalent iodine, iodopyridine, (dichloroiodo)arenes, oxidation, recyclable reagents 


\section{Introduction}

Organohypervalent iodine compounds are widely used in organic synthesis as versatile and environmentally friendly reagents for various oxidative transformations. ${ }^{1-7}$ In particular, (dichloroiodo)arenes, $\mathrm{ArICl}_{2}$, are commonly applied as efficient oxidants or chlorinating reagents. ${ }^{8}$ (Dichloroiodo)benzene $\mathbf{1}$ is one of the most common reagents that can be conveniently prepared by direct chlorination of iodobenzene. ${ }^{9}$ Numerous alternative procedures for oxidative chlorination of iodobenzene are also known, and a particularly useful method employs the combination of hydrochloric acid and inorganic oxidants such as $\mathrm{NaClO}$ or $\mathrm{NaClO}_{2}{ }^{10-13}$ Numerous (dichloroiodo)arenes and other organic iododichlorides (e.g., compounds 2-5 shown in Scheme 1) have been prepared by chlorination of the corresponding iodides using similar procedures. ${ }^{14-17}$

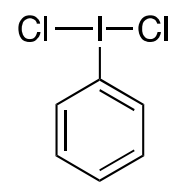

1

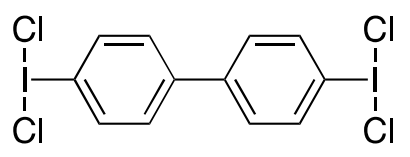

2

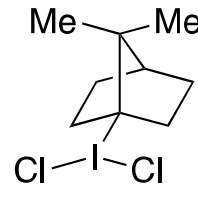

3

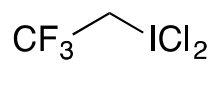

4<smiles>O=S(=O)(O)c1ccccc1</smiles>

5

Scheme 1. Representative examples of organic iododichlorides.

Recently, several pyridine-based hypervalent iodine compounds have been prepared and investigated. ${ }^{18-23}$ Most of these compounds are pyridine-derived iodonium salts, which can be used as effective electrophilic pyridine transfer reagents toward various organic substrates. The chemistry of pyridine-based hypervalent iodine compounds of general type $\mathrm{PyIX}_{2}$ remains undeveloped. Previously, our group reported the preparation of pyridine-based pentavalent iodine reagents, 2-iodylpyridines, by oxidation of corresponding 2-iodopyridines using 3,3-dimethyldioxirane. We have demonstrated that 2-iodylpyridines are useful oxidizing reagents towards alcohols or sulfides. ${ }^{24}$ However, to the best our knowledge, the pyridine based trivalent iodine reagents such as 2-(dichloroiodo)pyridine have not been reported. In the present paper, we report the synthesis, structural characterization, and reactivity of several (dichloroiodo)pyridine derivatives. These compounds can be used as efficient recyclable oxidants towards alcohols or chlorinating reagents towards electron-rich organic substrates.

\section{Results and Discussion}

In our initial experiments, we have found that the reaction of 2 -iodopyridine 6 with the $\mathrm{HCl}-\mathrm{NaOCl}$ combination for 2 hours at room temperature yields 2-(dichloroiodo)pyridine $\mathbf{7}$ in $89 \%$ yield (Scheme 2, eq. 1). The solid-state structure of $\mathbf{7}$ was established by single crystal X-ray crystallography (Figure 1). According to the X-ray crystallographic data, compound $\mathbf{7}$ has a T-shaped geometry of the iodine(III) center (the Cl1-I1-Cl2 bond angle is $\left.177.21(4)^{\circ}\right)$, and the bond distances between iodine and chlorine atoms are $2.4488(13) \AA$ (I1-Cl1) and 2.5274(12) $\AA$ (I1-Cl2). This molecular arrangement is similar to the previous reported structure of $\mathrm{PhICl}_{2}$ $1 .^{25}$ The $\mathrm{ICl}_{2}$ fragment in 7 is significantly rotated out of the pyridine plane $\left(50.14(11)^{\circ}\right)$. There are no close intermolecular contacts in the structure of $\mathbf{7}$ (the closest intermolecular $\mathrm{I}-\mathrm{Cl}$ contact is $3.627 \AA$ ). The analogous reaction of 2-iodo-3-propoxypyridine 8 under similar conditions gave the expected product $\mathbf{9}$ in $95 \%$ yield 
(Scheme 2, eq. 2). A single-crystal X-ray study of 9 revealed that this compound also has T-shaped geometry with the $\mathrm{Cl} 1-\mathrm{I} 1-\mathrm{Cl} 2$ angle of $170.12(5)^{\circ}$. Compound 9 has a pseudocyclic structure with an intramolecular interaction of 3.084(8) Å between the iodine center and the alkoxy group oxygen atom (Figure 1). ${ }^{24,26-29}$ Similar to 7, the $\mathrm{ICl}_{2}$ fragment is rotated out of the pyridine plane (85.46(9)). Two intermolecular I-Cl contacts at about $3.5 \AA$ are present in the $\mathrm{X}$-ray structure of $\mathbf{9}$ forming a trigonal-bipyramidal motif.

The chlorination of 3-iodopyridine $\mathbf{1 0}$ under similar conditions afforded 3-(dichloroiodo)pyridine $\mathbf{1 1}$ in $90 \%$ yield (Scheme 2, eq. 3), and the reaction of 4-iodopyridine 12 produced the expected dichloride 13 in $49 \%$ yield (Scheme 2, eq. 4).<smiles>Ic1ccccn1</smiles>

6<smiles>Ic1cccnc1</smiles>

10<smiles>[O-][NH+](Cl)O[V]Cl</smiles>

$7(89 \%)$<smiles>CI(Cl)c1cccnc1</smiles>

$11(90 \%)$ (eq. 1)

(eq. 3)<smiles>Ic1ccncc1</smiles>

12

8<smiles>[O-][NH+](Cl)O[V]Cl</smiles>

9 (95\%)

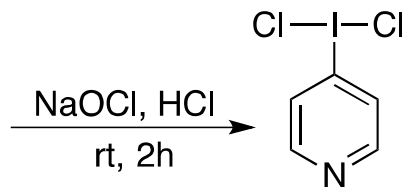

13 (49\%)

Scheme 2. Preparation of (dichloroiodo)pyridines.
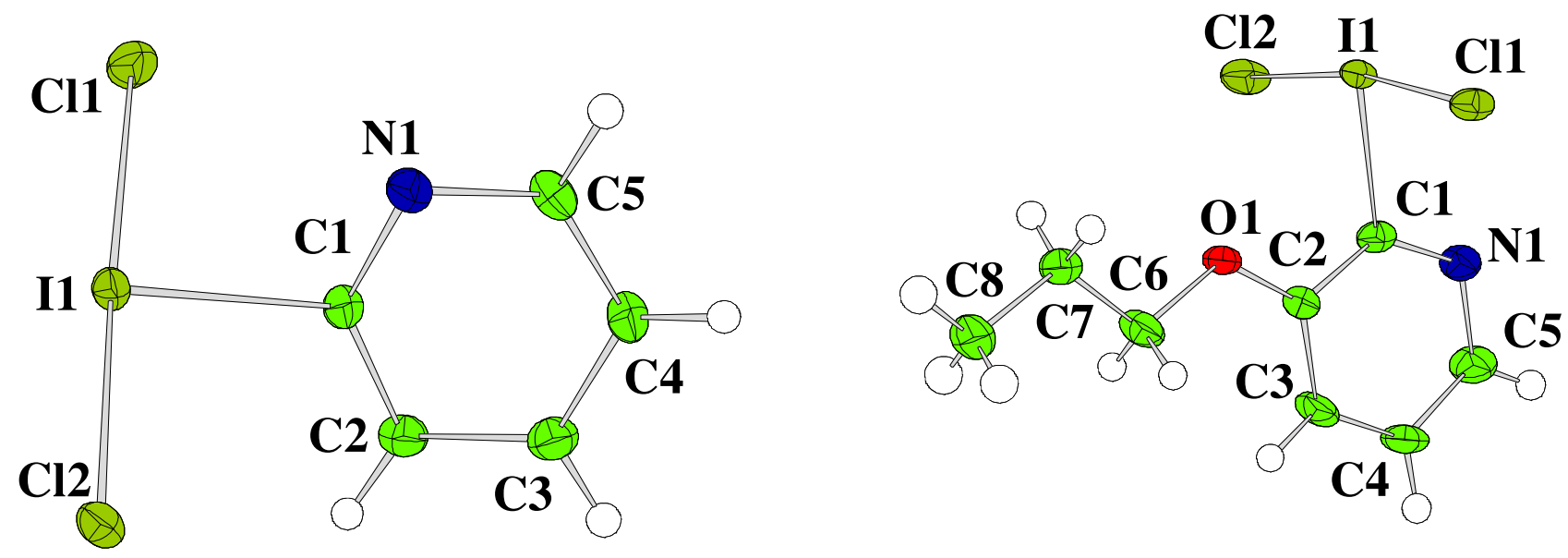

Figure 1. X-ray crystal structures of 2-(dichloroiodo)pyridines 7 and $\mathbf{9}$.

In general, dichloroiodoarene compounds, $\mathrm{ArICl}_{2}$, can serve as useful oxidants or efficient chlorinating reagents towards various organic substrates. ${ }^{11,30}$ We have investigated the oxidation of alcohols and oxidative chlorination of electron-rich organic substrates using (dichloroiodo)pyridines as reagents. The reaction of benzyl alcohol 14a with 2-iodopyridine dichloride 7 in acetonitrile solution at room temperature gave 
benzaldehyde 15a, isolated from reaction mixture as the 2,4-dinitrophenylhydrazone derivative in good yield (Table 1). As expected, the oxidation of benzyl alcohol 14a using other dichloroiodopyridines also produced benzaldehyde in good yields. In the reactions of para-chloro- 14b or para-nitro-benzyl alcohol 14c under similar conditions, the respective products were obtained in low to moderate yields. When the reaction of cycloheptanol 14d was performed using dichloroiodopyridines under these conditions, the expected ketone was obtained in moderate yields. Compared to the reactions of (dichloroiodo)benzene $\mathbf{1}$ under the same conditions, the new (dichloroiodo)pyridines afforded respective carbonyl compounds in comparable or better yields.

In the reaction of benzyl alcohol 14a with $\mathrm{PhICl}_{2}(\mathbf{1})$ in the presence of 2-iodopyridine (6) as additive, the yield of benzaldehyde was improved up to $81 \%$. This result implies that the pyridine moiety present in iodopyridines or (dichloroiodo)pyridines is facilitating the oxidation. Previously, Wicha and co-workers reported that the addition of pyridine resulted in increased reactivity of $\mathrm{PhICl}_{2}$ (1). ${ }^{31}$

Table 1. Oxidation of alcohols 14 using (dichloroiodo)pyridines ${ }^{a}$

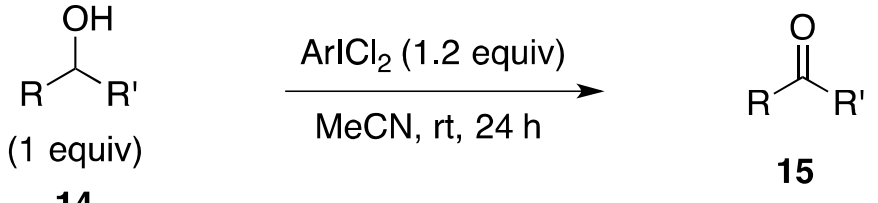

14

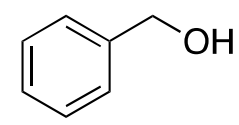

$14 a$<smiles>OCc1ccc(Cl)cc1</smiles>

$14 b$<smiles>O=[N+]([O-])c1ccc(CO)cc1</smiles>

$14 c$

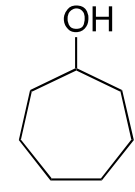

14d

\begin{tabular}{ccccc}
\hline & \multicolumn{4}{c}{ Product 15 (\%) } \\
\cline { 2 - 5 } $\mathrm{ArICl}_{2}$ & $\mathrm{C}_{6} \mathrm{H}_{5} \mathrm{CHO} 15 \mathrm{a}$ & $p-\mathrm{ClC}_{6} \mathrm{H}_{4} \mathrm{CHO}$ 15b & $p-\mathrm{NO}_{2} \mathrm{C}_{6} \mathrm{H}_{4} \mathrm{CHO}$ 15c & $C_{y c}-\mathrm{C}_{7} \mathrm{H}_{12} \mathrm{O}$ 15d \\
\hline 7 & $98 \%$ & $62 \%$ & $30 \%$ & $52 \%$ \\
9 & $84 \%$ & $69 \%$ & $19 \%$ & $37 \%$ \\
11 & $87 \%$ & $97 \%$ & $39 \%$ & $41 \%$ \\
13 & $84 \%$ & $61 \%$ & $13 \%$ & $30 \%$ \\
1 & $57 \%(81 \%)^{c}$ & $66 \%$ & $24 \%$ & $29 \%$ \\
\hline
\end{tabular}

${ }^{a}$ Reaction conditions: $\mathrm{ArICl}_{2}(0.300 \mathrm{mmol})$ and alcohol $14(0.250 \mathrm{mmol})$ stirred in acetonitrile $(2.0 \mathrm{~mL})$ at room temperature for 24 hours. ${ }^{b}$ Isolated yields as 2,4-dinitrophenylhydrazone derivatives of 15. ${ }^{\mathrm{c}}$ In the presence of 2-iodopyridine 6 (1.2 equiv).

In the next step, we have investigated the reactivity of (dichloroiodo)pyridines as chlorine atom transfer reagents towards organic substrates. The reaction of dibenzoylmethane 16 with 2-(dichloroiodo)pyridine 7 gave the corresponding $\alpha$-mono chloride $\mathbf{1 7}$ in good yield. As expected, the reactions of dibenzoylmethane 16 with other (dichloroiodo)pyridine reagents also produced product $\mathbf{1 7}$ in moderate yield. In the reactions of 1,4-dimethoxybenzene 18 with (dichloroiodo)pyridines, the corresponding product of monochlorination 19 was obtained in moderate yield. Compared to the reactions of (dichloroiodo)benzene $\mathbf{1}$ or analogous 
(dichloroiodo)arenes under similar conditions, the (dichloroiodo)pyridine reagents showed better reactivity and higher yields. ${ }^{32-34}$ Among the chlorination reactions, the reactions of 4-(dichloroiodo)pyridine 13 gave the lowest yields because of the low solubility of this reagent in methylene chloride.<smiles>O=C(CC(=O)c1ccccc1)c1ccccc1</smiles>

(1.0 equiv)

16

$$
\underset{\mathrm{CH}_{2} \mathrm{Cl}_{2}, \mathrm{rt}, 24 \mathrm{~h}}{\stackrel{\mathrm{ArICl}_{2}(1.2 \text { equiv })}{\longrightarrow}}
$$<smiles>O=C(C(Cl)c1ccccc1)C(Cl)c1ccccc1</smiles>

17

\begin{tabular}{cccccc}
$\mathrm{ArICl}_{2}:$ & $\mathbf{7}$ & $\mathbf{9}$ & $\mathbf{1 1}$ & $\mathbf{1 3}$ & $\mathbf{1}$ \\
\hline Yield of $\mathbf{1 7}(\%)$ & $97 \%$ & $78 \%$ & $85 \%$ & $57 \%$ & $70 \%$
\end{tabular}

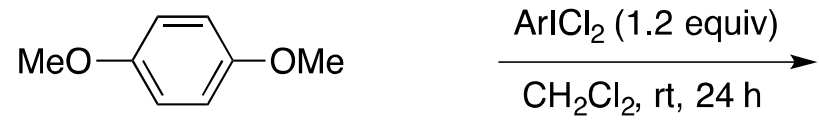

(1.0 equiv)

18

$$
\underset{\mathrm{CH}_{2} \mathrm{Cl}_{2}, \mathrm{rt}, 24 \mathrm{~h}}{\stackrel{\mathrm{ArICl}_{2}}{\longrightarrow} \text { (1.2 equiv) }}
$$

$\mathrm{Cl}$

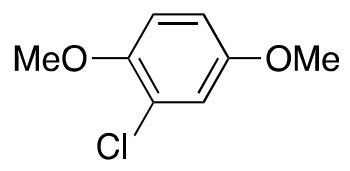

19

\begin{tabular}{cccccc}
$\mathrm{ArlCl}_{2}$ & $\mathbf{7}$ & $\mathbf{9}$ & $\mathbf{1 1}$ & 13 & 1 \\
\hline $19(\%)$ & $78 \%$ & $81 \%$ & $84 \%$ & $47 \%$ & $68 \%$
\end{tabular}

Scheme 2. Oxidative chlorination using (dichloroiodo)pyridine reagents.

Finally, we have demonstrated that 2-(dichloroiodo)-3-propoxypyridine 9 can be used as a recyclable reagent. The reduced form of reagent 9, 2-iodo-3-propoxypyridine $\mathbf{8}$, can be easily recovered from the reaction mixture in over $85 \%$ yield by a simple acid-base liquid-liquid biphasic protocol. The recovered compound 8 can be converted to 2-(dichloroiodo)-3-propoxypyridine 9 using standard procedure. ${ }^{24}$

\section{Conclusions}

In summary, we have prepared new (dichloroiodo)pyridines from respective iodopyridines by chlorination with the $\mathrm{HCl} / \mathrm{NaOCl}$ combination. Structures of 2-(dichloroiodo)pyridine 7 and 2-(dichloroiodo)-3propoxypyridine 9 were established by X-ray crystallography. According to the crystal data, both compounds have the typical for hypervalent iodine T-shape structure. Compound $\mathbf{9}$ has a pseudocyclic structure with a short intramolecular interaction between oxygen atom and iodine center. The new (dichloroiodo)pyridines can be used as efficient reagents for oxidation of alcohols to carbonyl compounds and also as chlorinating reagents. The reduced form of the reagents, in particular, 2-iodo-3-propoxypyridine, can be recovered from the reaction mixture in good yields by an acid-base liquid-liquid biphasic protocol.

\section{Experimental Section}

General. All reactions were performed under dry argon atmosphere with flame-dried glassware. Dichloromethane and acetonitrile were distilled from $\mathrm{CaH}_{2}$ immediately prior to use. All commercial reagents were ACS reagent grade and used without further purification. Melting points were determined in an open 
capillary tube with a Mel-temp II melting point apparatus. NMR spectra were recorded on a Varian Inova 500 $\mathrm{MHz}\left({ }^{1} \mathrm{H}\right.$ NMR). Chemical shifts are reported in parts per million (ppm) and referenced relative to the tetramethylsilane. The known compounds, 3-propoxy-2-iodopyridine $(\mathbf{8})^{24}$ and dichloroiodobenzene $(\mathbf{1})^{9}$ were prepared according to the reported procedures.

\section{General Procedure for preparation of (dichloroiodo)pyridines}

Aqueous $12 \mathrm{M} \mathrm{HCl}$ solution $(1.5 \mathrm{~mL}$ ) was added to a mixture of iodoarene (1.4 to $2.0 \mathrm{mmol}$ ) with $5.85 \%$ aqueous $\mathrm{NaOCl}(8.0 \mathrm{~mL})$. The reaction was stirred at room temperature for $2 \mathrm{~h}$ (reaction completion was controlled by TLC), and the reaction mixture changed from a light yellow solution to a yellow suspension. After completion of the reaction, the resulting yellow precipitate was separated by filtration. The precipitate was washed with hexane and dried in vacuum to afford analytically pure (dichloroiodo)pyridine product.

2-(Dichloroiodo)pyridine (7). Chlorination of 2-iodopyridine $6(410 \mathrm{mg}, 2.00 \mathrm{mmol}$ ) according to the general procedure afforded $490 \mathrm{mg}(89 \%)$ of product 7, isolated as a yellow solid: $\mathrm{mp} 79.5-81.1{ }^{\circ} \mathrm{C}$ (from methylene chloride); IR (KBr) cm ${ }^{-1} 3077,1556,1444,1412 ;{ }^{1} \mathrm{H} N M R\left(500 \mathrm{MHz} \mathrm{CDCl}_{3}\right): \delta 8.53(\mathrm{dd}, \mathrm{J} 4.9 \mathrm{~Hz}, 1.8 \mathrm{~Hz}, 1 \mathrm{H})$, 8.19 (dd, J $8.3 \mathrm{~Hz}, 0.5 \mathrm{~Hz}, 1 \mathrm{H}$ ), 7.84 (ddd, J $8.3 \mathrm{~Hz}, 7.4 \mathrm{~Hz}, 1.8 \mathrm{~Hz}, 1 \mathrm{H}$ ), 7.59 (ddd, J $7.4 \mathrm{~Hz}, 4.9 \mathrm{~Hz}, 0.5 \mathrm{~Hz}, 1 \mathrm{H}$ ); ${ }^{13} \mathrm{C}$ NMR (125 MHz, $\left.\mathrm{CDCl}_{3}\right): \delta 150.8,144.8,141.5,129.9,127.6 ;$ Anal. Calcd forC ${ }_{5} \mathrm{H}_{4} \mathrm{Cl}_{2} \mathrm{IN}$ : C, 21.77; $\mathrm{H}, 1.46 ; \mathrm{N}, 5.08$. Found: C, 22.04; H,1.30; N, 5.08\%.

Single crystals of product 7 suitable for X-ray crystallographic analysis were obtained by slow evaporation of $\mathrm{MeCN}-\mathrm{CH}_{2} \mathrm{Cl}_{2}$ solution. For details on crystal structure of compound 7 see the CIF file in Supporting Information. Selected crystallographic data for 7: Triclinic P-1 a 4.0281(3) A, b 8.6219(6) $\AA$, c 11.7755(11) $\AA, \alpha=$ $73.583(5)^{\circ}, \beta=88.270(6)^{\circ}, \gamma=80.810(6)^{\circ}, V=387.20(5) \AA^{3}, Z=2, R(I>2.0 / \sigma(I))=0.0204, R_{w}($ all $)=0.0640$, CCDC 1563656.

2-(Dichloroiodo)-3-propoxypyridine (9). Chlorination of 2-iodo-3-propoxypyridine 8 (375 mg, $1.43 \mathrm{mmol}$ ) according to the general procedure afforded $452 \mathrm{mg}$ (95\%) of product 9, isolated as a yellow solid: $\mathrm{mp} 89.1-$ $90.5{ }^{\circ} \mathrm{C}$ (from methylene chloride); IR (KBr) cm ${ }^{-1} 3071,2964,2877,1559,1443,1411,1290,1043 ;{ }^{1} \mathrm{H} N M R(500$ $\mathrm{MHz}, \mathrm{CDCl}_{3}$ ): $\delta 8.05$ (dd, J $4.4 \mathrm{~Hz}, 1.4 \mathrm{~Hz}, 1 \mathrm{H}$ ), 7.53 (dd, J $8.3 \mathrm{~Hz}, 4.4 \mathrm{~Hz}, 1 \mathrm{H}$ ), 7.41 (dd, J $8.3 \mathrm{~Hz}, 1.4 \mathrm{~Hz}, 1 \mathrm{H}$ ), 4.21 $(\mathrm{t}, J 6.3 \mathrm{~Hz}, 2 \mathrm{H}), 2.06-1.93(\mathrm{~m}, 2 \mathrm{H}), 1.16(\mathrm{t}, J 7.5 \mathrm{~Hz}, 3 \mathrm{H}) ;{ }^{13} \mathrm{C} N M R\left(125 \mathrm{MHz}, \mathrm{CDCl}_{3}\right): \delta 149.5,141.4,139.2$, 128.9, 121.8, 72.2, 22.3, 10.5; Anal. Calcd forC $\mathrm{C}_{8} \mathrm{H}_{10} \mathrm{INCl}_{2}$ : C, 28.77; H, 3.02; N, 4.19. Found: C, 28.77; H,2.89; N, 4.15 .

Single crystals of product $\mathbf{9}$ suitable for X-ray crystallographic analysis were obtained by slow evaporation of $\mathrm{MeCN}-\mathrm{CH}_{2} \mathrm{Cl}_{2}$ solution. For details on crystal structure of compound $\mathbf{9}$ see the CIF file in Supporting Information. Selected crystallographic data for 9: Orthorhombic, P2 ${ }_{1} 2_{1} 2_{1}, a=8.0475(5) \AA, b=10.3684(5) \AA, c=$ 13.9105(9) $\AA$, $V=1160.69(12) \AA^{3}, Z=4, R(I>2.0 / \sigma(I))=0.0379, R_{w}($ all $)=0.0659$, CCDC 1563657.

3-(Dichloroiodo)pyridine $(\mathbf{1 1})^{35}$ : Chlorination of 3-iodopyridine 10 (410 $\mathrm{mg}, 2.00 \mathrm{mmol}$ ) according to the general procedure afforded $498 \mathrm{mg}(90 \%)$ of product 11, isolated as a yellow solid: $\mathrm{mp} 130.5-132.0{ }^{\circ} \mathrm{C}$ (from methylene chloride) (lit, $\left.{ }^{35} \mathrm{mp} 128-129^{\circ} \mathrm{C}\right)$; IR (neat) $\mathrm{cm}^{-1} 3007,2986,2921,1568,1459 ;{ }^{1} \mathrm{H} \mathrm{NMR}(500 \mathrm{MHz}$, DMSO- $\left.d_{6}\right): \delta 9.10(\mathrm{~s}, 1 \mathrm{H}), 8.87-8.78(\mathrm{~m}, 1 \mathrm{H}), 8.73(\mathrm{~d}, J 7.0 \mathrm{~Hz}, 1 \mathrm{H}), 7.75-7.63(\mathrm{~m}, 1 \mathrm{H}) ;{ }^{13} \mathrm{C} \mathrm{NMR}(75 \mathrm{MHz}$, DMSO$\left.d_{6}\right): \delta 151.8,149.5,142.9,128.1,96.3$; HRMS (APCl-positive ionization): calcd for $\mathrm{C}_{5} \mathrm{H}_{5}{ }^{35} \mathrm{Cl}_{2} \mathrm{IN}\left([\mathrm{M}+\mathrm{H}]^{+}\right)$: 275.8844, found: 275.8860 .

4-(Dichloroiodo)pyridine (13): Chlorination of 4-iodopyridine 12 (410 mg, $2.00 \mathrm{mmol}$ ) according to the general procedure afforded $270 \mathrm{mg}(49 \%)$ of product 10 , isolated as yellow solid: $\mathrm{mp} 109.5-110.1{ }^{\circ} \mathrm{C}$ (from methylene chloride); IR (neat) $\mathrm{cm}^{-1} ; 3103,2915,2846,1617,1481 ;{ }^{1} \mathrm{H}$ NMR $\left(500 \mathrm{MHz}, \mathrm{DMSO}-d_{6}\right): \delta 8.49(\mathrm{~d}, J 5.0 \mathrm{~Hz}, 2 \mathrm{H})$, 
$8.40(\mathrm{~d}, J 5.0 \mathrm{~Hz}, 2 \mathrm{H}) ;{ }^{13} \mathrm{C}$ NMR (75 MHz, DMSO-d $)_{6}$ : $\delta$ 142.2, 136.3, 120.3; HRMS (APCl-positive ionization): calcd for $\left.\mathrm{C}_{5} \mathrm{H}_{5}\right|^{35} \mathrm{Cl}_{2} \mathrm{~N}\left([\mathrm{M}+\mathrm{H}]^{+}\right): 275.8844$, found: 275.8816 .

\section{General procedure for oxidation of alcohols using (dichloroiodo)arenes}

Alcohol $14(0.250 \mathrm{mmol})$ was added to a solution of (dichloroiodo)arene $(0.300 \mathrm{mmol})$ in acetonitrile $(2 \mathrm{~mL})$. The reaction was stirred at room temperature for $24 \mathrm{~h}$. After completion of the reaction, a standard solution

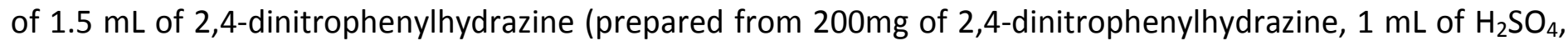
$10 \mathrm{~mL}$ of $\mathrm{EtOH}$, and $2 \mathrm{~mL}$ of $\mathrm{H}_{2} \mathrm{O}$ ) was added. The precipitate of 2,4-dinitrophenylhydrazone derivative 15 was filtered, washed with water, and dried in vacuum.

2,4-Dinitrophenylhydrazone of benzaldehyde (15a): ${ }^{24}$ Reaction of benzyl alcohol $14 a(27 \mathrm{mg}, 0.250 \mathrm{mmol})$ according to the general procedure afforded 2,4-dinitrophenylhydrazone of 15a (57-98\%), isolated as a light orange solid: $\mathrm{mp} 231.7-233.2{ }^{\circ} \mathrm{C}$ (from ethanol) (lit, ${ }^{24} \mathrm{mp} 235.8-237.0{ }^{\circ} \mathrm{C}$ ); ${ }^{1} \mathrm{H}$ NMR $\left(500 \mathrm{MHz}, \mathrm{DMSO}-d_{6}\right): \delta 11.7$ (s, 1H), $8.86(\mathrm{~d}, J 0.3 \mathrm{~Hz}, 1 \mathrm{H}), 8.70(\mathrm{~s}, 1 \mathrm{H}), 8.37$ (dd, J $10.0 \mathrm{~Hz}, 0.3 \mathrm{~Hz}, 1 \mathrm{H}), 8.10$ (d, J $10.0 \mathrm{~Hz}, 1 \mathrm{H}), 7.79$ (dd, J 7.5 $\mathrm{Hz}, 2.0 \mathrm{~Hz}, 2 \mathrm{H}), 7.50-7.42(\mathrm{~m}, 3 \mathrm{H})$.

2,4-Dinitrophenylhydrazone of $p$-chlorobenzaldehyde (15b): ${ }^{36}$ Reaction of $p$-chlorobenzyl alcohol $14 \mathbf{b}$ (36 mg, $0.250 \mathrm{mmol}$ ) according to the general procedure afforded 2,4-dinitrophenylhydrazone of 15b (61-97\%), isolated as a light orange solid: $\mathrm{mp} 256.0-258.7{ }^{\circ} \mathrm{C}$ (from ethanol) (lit, ${ }^{36} \mathrm{mp} 264.0{ }^{\circ} \mathrm{C}$ ); ${ }^{1} \mathrm{H} \mathrm{NMR}(500 \mathrm{MHz}$, DMSO- $\left.d_{6}\right): \delta 11.7(\mathrm{~s}, 1 \mathrm{H}), 8.86(\mathrm{~d}, J 0.3 \mathrm{~Hz}, 1 \mathrm{H}), 8.69(\mathrm{~s}, 1 \mathrm{H}), 8.37(\mathrm{dd}, J 9.5 \mathrm{~Hz}, 0.3 \mathrm{~Hz}, 1 \mathrm{H}), 8.10(\mathrm{~d}, J 9.5 \mathrm{~Hz}, 1 \mathrm{H})$, $7.81(\mathrm{~d}, J 8.3 \mathrm{~Hz}, 2 \mathrm{H}), 7.55$ (d, J $8.3 \mathrm{~Hz}, 2 \mathrm{H})$.

2,4-Dinitrophenylhydrazone of $p$-nitrobenzaldehyde (15c): ${ }^{37}$ Reaction of $p$-nitrobenzyl alcohol $14 \mathrm{c}(38 \mathrm{mg}$, $0.250 \mathrm{mmol}$ ) according to the general procedure afforded 2,4-dinitrophenylhydrazone of 15c (13-39\%), isolated as a light orange solid: $\mathrm{mp} 293.5-295.0{ }^{\circ} \mathrm{C}$ (from ethanol) (lit, $\left.{ }^{37} \mathrm{mp} \mathrm{278.0-280.0}{ }^{\circ} \mathrm{C}\right) ;{ }^{1} \mathrm{H} \mathrm{NMR}(500 \mathrm{MHz}$, DMSO- $\left.d_{6}\right): \delta 11.8(\mathrm{~s}, 1 \mathrm{H}), 8.88(\mathrm{~d}, J 0.3 \mathrm{~Hz}, 1 \mathrm{H}), 8.81(\mathrm{~s}, 1 \mathrm{H}), 8.42(\mathrm{dd}, J 9.8 \mathrm{~Hz}, 0.3 \mathrm{~Hz}, 1 \mathrm{H}), 8.32(\mathrm{~d}, J 8.5 \mathrm{~Hz}, 2 \mathrm{H})$, $8.17(\mathrm{~d}, J 9.8 \mathrm{~Hz}, 1 \mathrm{H}), 8.05(\mathrm{~d}, J 8.5 \mathrm{~Hz}, 2 \mathrm{H})$.

2,4-Dinitrophenylhydrazone of cycloheptanone $(\mathbf{1 5 d}):^{24}$ Reaction of cycloheptanol $14 \mathrm{~d}(29 \mathrm{mg}, 0.250 \mathrm{mmol})$ according to the general procedure afforded 2,4-dinitrophenylhydrazone of 15d (29-52\%), isolated as a yellow solid: $\mathrm{mp} 146.8-148.3{ }^{\circ} \mathrm{C}$ (from ethanol) (lit, $\left.{ }^{24} \mathrm{mp} 147.0-147.2{ }^{\circ} \mathrm{C}\right) ;{ }^{1} \mathrm{H} \mathrm{NMR}\left(500 \mathrm{MHz}, \mathrm{CDCl}_{3}\right): \delta 11.0(\mathrm{~s}, 1 \mathrm{H}$ ), $9.13(\mathrm{~d}, J 2.5 \mathrm{~Hz}, 1 \mathrm{H}), 8.30$ (dd, J $9.8 \mathrm{~Hz}, 2.5 \mathrm{~Hz}, 1 \mathrm{H}), 7.99$ (d, J $9.8 \mathrm{~Hz}, 1 \mathrm{H}), 2.68-2.52(\mathrm{~m}, 4 \mathrm{H}), 1.94-1.80(\mathrm{~m}, 2 \mathrm{H})$, $1.77-1.51(\mathrm{~m}, 6 \mathrm{H})$.

\section{General procedure for chlorination of dibenzoylmethane 16 using (dichloroiodo)arenes}

Dibenzoylmethane $16(0.250 \mathrm{mmol})$ was added to a solution of $\mathrm{ArICl}_{2}(0.300 \mathrm{mmol})$ in dichloromethane $(2 \mathrm{~mL})$. The reaction was stirred at room temperature for $24 \mathrm{~h}$. After completion of the reaction, $5 \%$ aqueous $\mathrm{Na}_{2} \mathrm{~S}_{2} \mathrm{O}_{3}$ $(5 \mathrm{~mL})$ was added, and the mixture was extracted with dichloromethane. The organic phase was dried over anhydrous $\mathrm{Na}_{2} \mathrm{SO}_{4}$ and concentrated under reduced pressure. Purification by short column chromatography (hexane-ethyl acetate $=5: 1$ ) afforded analytically pure mono-chlorination product 17 .

2-Chloro-1,3-diphenylpropane-1,3-dione (17): ${ }^{38}$ Reaction of dibenzoylmethane 16 (56 mg, $0.250 \mathrm{mmol}$ ) according to the general procedure afforded product 17 (57-97\%), isolated as a yellow solid: $\mathrm{mp} 77.1-79.5{ }^{\circ} \mathrm{C}$ (from methylene chloride) (lit, $\left.{ }^{38} \mathrm{mp} 86.0-87.0{ }^{\circ} \mathrm{C}\right) ;{ }^{1} \mathrm{H} \mathrm{NMR}\left(500 \mathrm{MHz}, \mathrm{CDCl}_{3}\right): \delta 7.99(\mathrm{~d}, J 8.0 \mathrm{~Hz}, 4 \mathrm{H}), 7.63-7.58$ (m, 2H), $7.47(\mathrm{t}, J 7.8 \mathrm{~Hz}, 4 \mathrm{H}), 6.41(\mathrm{~s}, 1 \mathrm{H})$.

\section{General procedure for chlorination of 1,4-dimethoxybenzene 18 using (dichloroiodo)arenes}

1,4-Dimethoxybenzene $18(0.250 \mathrm{mmol})$ was added to a solution of (dichloroiodo)arene $(0.300 \mathrm{mmol})$ in dichloromethane $(2 \mathrm{~mL})$. The reaction was stirred at room temperature for $24 \mathrm{~h}$. After completion of the reaction, $5 \%$ aqueous $\mathrm{Na}_{2} \mathrm{~S}_{2} \mathrm{O}_{3}(5 \mathrm{~mL})$ was added, and the mixture was extracted with dichloromethane. The 
organic phase was dried over anhydrous $\mathrm{Na}_{2} \mathrm{SO}_{4}$ and concentrated under reduced pressure. Purification by short column chromatography (hexane-ethyl acetate $=10: 1$ ) afforded analytically pure mono-chlorination product 19.

2-Chloro-1,4-dimethoxybenzene (19): ${ }^{39}$ Reaction of 1,4-dimethoxybenzene 18 (35 mg, 0.250 mmol) according to the general procedure afforded product 19 (47-84\%), isolated as a yellow oil; ${ }^{1} \mathrm{H} \mathrm{NMR}\left(500 \mathrm{MHz}^{\mathrm{CDCl}}\right)_{3}: \delta$ $6.96(d, J 3.0 \mathrm{~Hz}, 1 \mathrm{H}), 6.86$ (d, J $9.0 \mathrm{~Hz}, 1 \mathrm{H}), 6.77$ (dd, J $9.0 \mathrm{~Hz}, 3.0 \mathrm{~Hz}, 1 \mathrm{H}), 3.85$ (s, 3H), 3.76 (s, 3H).

\section{Recovery of 2-iodo-3-propoxypyridine 8}

After completion of the reaction of benzyl alcohol 14 a with reagent 9, 20\% $\mathrm{H}_{2} \mathrm{SO}_{4}(3.0-5.0 \mathrm{~mL})$ was added. The mixture was extracted with dichloromethane. Treatment of the organic layer according to general procedures for oxidation of benzyl alcohol or chlorination afforded product 15a. To the aqueous layer $20 \% \mathrm{NaOH}(5.0-7.0$ $\mathrm{mL}$ ) was added, and then the mixture was extracted with dichloromethane. The organic solution was dried over anhydrous $\mathrm{Na}_{2} \mathrm{SO}_{4}$ and concentrated in vacuum to give 2-iodo-3-propoxypyridine 8 (70 mg, 89\%).

After completion of the reaction of 1,4-dimethoxybenzene 18 with reagent 9, $20 \% \mathrm{H}_{2} \mathrm{SO}_{4}(3.0-5.0 \mathrm{~mL})$ was added. The mixture was extracted with dichloromethane. Treatment of the organic layer according to general procedures for chlorination of 1,4-dimethoxybenzene afforded product 19. To the aqueous layer $20 \% \mathrm{NaOH}$ (5.0-7.0 $\mathrm{mL}$ ) was added, and then the mixture was extracted with dichloromethane. The organic solution was dried over anhydrous $\mathrm{Na}_{2} \mathrm{SO}_{4}$ and concentrated in vacuum to give 2-iodo-3-propoxypyridine 8 (67 mg, $85 \%$ ).

\section{Acknowledgements}

This work was supported by a research grant from the NSF (CHE-1262479) and Tomsk Polytechnic University (VIU-316/2017).

\section{Supplementary Material}

NMR spectra of all reagents and products are given in the associated Supplementary Data File. The crystal data files can be retrieved from the Cambridge Crystallography Data Center as CCDC numbers 1563656 (compound 7) and 1563657 (compound 9).

\section{References}

1. Wirth, T.; Ed. Top. Curr. Chem. 2016, 373.

2. Zhdankin, V. V. In Hypervalent lodine Chemistry: Preparation, Structure and Synthetic Application of Polyvalent lodine Compounds; J ohn Wiley \& Sons Ltd: 2014.

3. Yoshimura, A.; Zhdankin, V. V. Chem. Rev. 2016, 116, 3328-3435. https://doi.org/10.1021/acs.chemrev.5b00547

4. Dohi, T.; Kita, Y. Curr. Org. Chem. 2016, 20, 580-615. https://doi.org/10.2174/1385272819666150716173142

5. Kohlhepp, S. V.; Gulder, T. Chem. Soc. Rev. 2016, 45, 6270-6288. https://doi.org/10.1039/C6CS00361C

6. Saito, A. Arkivoc 2017, (i) 84-98. http://dx.doi.org/10.3998/ark.5550190.p009.965 
7. Li, Y.; Hari, D. P.; Vita, M. V.; Waser, J . Angew. Chem., Int. Ed. 2016, 55, 4436-4454. https://doi.org/10.1002/anie.201509073

8. Arnold, A. M.; Ulmer, A.; Gulder, T. Chem. - Eur. J . 2016, 22, 8728-8739.

https://doi.org/10.1002/chem.201600449

9. Podgorsek, A.; Iskra, J. Molecules 2010, 15, 2857-2871.

https://doi.org/10.3390/molecules15042857

10. Carle, M. S.; Shimokura, G. K.; Murphy, G. K. Eur. J . Org. Chem. 2016, 3930-3933.

https://doi.org/10.1002/eJ oc.201600714

11. Zhao, X.-F.; Zhang, C. Synthesis 2007, 551-557.

12. Tao, J .; Tran, R.; Murphy, G. K. J . Am. Chem. Soc. 2013, 135, 16312-16315.

https://doi.org/10.1021/J a408678p

13. Garve, L. K. B.; Barkawitz, P.; J ones, P. G.; Werz, D. B. Org. Lett. 2014, 16, 5804-5807. https://doi.org/10.1021/ol5029139

14. Yusubov, M. S.; Drygunova, L. A.; Zhdankin, V. V. Synthesis 2004, 2289-2292.

https://doi.org/10.1055/s-2004-831175

15. Dence, J . B.; Roberts, J . D. J . Org. Chem. 1968, 33, 1251-1253.

https://doi.org/10.1021/J o01267a073

16. Bravo, P.; Montanari, V.; Resnati, G.; DesMarteau, D. D. J . Org. Chem. 1994, 59, 6093-6094. https://doi.org/10.1021/J o00099a048

17. Varella, E.; Varvoglis, A. Phosphorus, Sulfur, Silicon, Related Elements 1991, 55, 275-277. https://doi.org/10.1080/10426509108045951

18. Das, P.; Takada, M.; Matsuzaki, K.; Saito, N.; Shibata, N. Chem. Commun. (Cambridge, U. K.) 2017, 53, 3850-3853.

https://doi.org/10.1039/C7CC01043E

19. Bielawski, M.; Malmgren, J .; Pardo, L. M.; Wikmark, Y.; Olofsson, B. ChemistryOpen 2014, 3, 19-22. https://doi.org/10.1002/open.201300042

20. Bielawski, M.; Zhu, M.; Olofsson, B. Adv. Synth. Catal. 2007, 349, 2610-2618.

https://doi.org/10.1002/adsc.200700373

21. Aggarwal, V. K.; Olofsson, B. Angew. Chem., Int. Ed. 2005, 44, 5516-5519.

https://doi.org/10.1002/anie.200501745

22. Liu, C.; Wang, Q. Org. Lett. 2016, 18, 5118-5121. https://doi.org/10.1021/acs.orglett.6b02550

23. Bielawski, M.; Olofsson, B. Chem. Commun. 2007, 2521-2523.

https://doi.org/10.1039/b701864a

24. Yoshimura, A.; Banek, C. T.; Yusubov, M. S.; Nemykin, V. N.; Zhdankin, V. V. J . Org. Chem. 2011, 76, 38123819.

https://doi.org/10.1021/J o200163m

25. Archer, E. M.; van Schalkwyk, T. G. D. Acta Cryst. 1953, 6, 88-92.

https://doi.org/10.1107/S0365110X53000193

26. Yoshimura, A.; Yusubov, M. S.; Zhdankin, V. V. Org. Biomol. Chem. 2016, 14, 4771-4781. https://doi.org/10.1039/C60B00773B

27. Yoshimura, A.; Nemykin, V. N.; Zhdankin, V. V. Chem.--Eur. J . 2011, 17, 10538-10541.

https://doi.org/10.1002/chem.201102265 
28. Zhu, C.; Yoshimura, A.; Solntsev, P.; J i, L.; Wei, Y.; Nemykin, V. N.; Zhdankin, V. V. Chem. Commun. 2012, 48, 10108-10110.

https://doi.org/10.1039/c2cc35708a

29. Zhu, C.; Yoshimura, A.; J i, L.; Wei, Y.; Nemykin, V. N.; Zhdankin, V. V. Org. Lett. 2012, 14, 3170-3173. https://doi.org/10.1021/ol301268J

30. Duan, X.; Zhou, H.; Tian, X.; Liu, J .; Ma, J. Synthesis 2015, 47, 777-782.

https://doi.org/10.1055/s-0034-1379973

31. Wicha, J .; Zarecki, A.; Kocor, M. Tetrahedron Lett. 1973, 37, 3635-3638.

https://doi.org/10.1016/S0040-4039(01)86993-8

32. Chen, J .-M.; Zeng, X.-M.; Middleton, K.; Zhdankin, V. V. Tetrahedron Lett. 2011, 52, 1952-1955. https://doi.org/10.1016/J .tetlet.2011.02.065

33. Thorat, P. B.; Bhong, B. Y.; Karade, N. N. Synlett 2013, 24, 2061-2066.

https://doi.org/10.1055/s-0033-1339495

34. Podgorsek, A.; J urisch, M.; Stavber, S.; Zupan, M.; Iskra, J .; Gladysz, J . A. J . Org. Chem. 2009, 74, 31333140.

https://doi.org/10.1021/J 0900233h

35. Woodcraft, J. Int. Pat. Appl. WO2010018218 (A2), 2010.

36. Aiyalu, R.; Sankaranarayanan, M. Acta Pharm. Sci. 2008, 50, 153-162.

37. Zhu, C.; Yoshimura, A.; Wei, Y.; Nemykin, V. N.; Zhdankin, V. V. Tetrahedron Lett. 2012, 53, 1438-1444. https://doi.org/10.1016/J .tetlet.2012.01.053

38. Kitamura, T.; Tazawa, Y.; Morshed, M. H.; Kobayashi, S. Synthesis 2012, 44, 1159-1162. https://doi.org/10.1055/s-0031-1290578

39. Karade, N. N.; Tiwari, G. B.; Huple, D. B.; Siddiqui, T. A. J . J . Chem. Res. 2006, 366-368. https://doi.org/10.3184/030823406777946761 